\title{
Expression of Thyroid Hormone Receptor Isoforms Down- regulated by Thyroid Hormone in Human Medulloblastoma Cells
}

\author{
TSUYOSHI MONDEN, YASUYO NAKAJIMA*, TETSU HASHIDA*, SUMIYASU ISHII*, TAKUYA TOMARU*, \\ NOBUYUKI SHIBUSAWA*, KOSHI HASHIMOTO*, TETUROU SATOH*, MASANOBU YAMADA*, \\ MASATOMO MORI* AND KIKUO KASAI
}

Department of Endocrinology and Metabolism, Dokkyo University School of Medicine, Mibu, Tochigi 321-0293 Japan

*Department of Medicine and Molecular Science, Gunma University Graduate School of Medicine, Maebashi, Gunma 371-8511 Japan

\begin{abstract}
The role of thyroid hormone (T3) in the regulation of growth and development of the central nervous system including the cerebellum has been well established. However, the effects of thyroid hormone on malignant tumors derived from the cerebellum remain poorly understood. Our analysis mainly focused on expression levels of TR isoforms and the effects of thyroid hormone in human medulloblastoma HTB-185 cells. Northern blot analysis revealed TR $\alpha 2$ mRNA but not TR $\alpha 1, \beta 1$ or $\beta 2$ mRNA in the cell. The TR $\alpha 1$ and TR $\beta 1$ mRNAs were detected only by RT-PCR method and TR $\beta 2$ was not expressed. Incubation of $\mathrm{T} 3$ for $24 \mathrm{~h}$ decreased TR $\alpha 1$, TR $\alpha 2$ and TR $\beta 1$ mRNA. Addition of actinomycin D caused an acute increase in the basal TR mRNA levels and the rate of decrease of all kinds of TR isoform mRNA was accelerated in the T3-treated groups compared to controls, indicating that the stability of TR mRNA was affected by T3. Incubation with cycloheximide also blocked a decrease in TR mRNA levels in the T3-treated HTB-185 cells suggesting that down-regulation of TR mRNA required the synthesis of new protein. Our data provide novel evidence for the expression of TRs down-regulated by T3 in HTB-185 cells, suggesting that TR expression is post-transcriptionally regulated by $\mathrm{T} 3$ at the level of RNA stability.
\end{abstract}

Key words: Thyroid hormone, Thyroid hormone receptor, mRNA, Cerebellum, Medulloblastoma

(Endocrine Journal 53: 181-187, 2006)

THE role of thyroid hormone (T3) in the regulation of growth and development of the central nervous system has been well established [1,2]. T3 actions in the brain are exerted through their receptors and the gene transcription mediated by these receptors [3] depends on recruited co-activators $[4,5]$. Thyroid hormone receptors (TRs) belong to a gene superfamily which includes the receptors for the glucocorticoids, sex steroids [6], vitamin $\mathrm{D}$ and retinoic acid. Four different isoforms of TR $\alpha 1, T R \alpha 2$ (TR $\alpha 2$ does not bind T3), TR $\beta 1$ and

Received: February 10, 2005

Accepted: December 20, 2005

Correspondence to: Tsuyoshi MONDEN, M.D., Ph.D., Department of Endocrinology and Metabolism, Dokkyo Medical University School of Medicine, 880 Kitakobayashi, Mibu, Shimotsuga-gun, Tochigi 321-0293, Japan
TR $\beta 2$ were identified in various tissues including those of the central nervous system [7-11]. Recently, a novel TR $\beta 3$ isoform containing a unique 23-amino-acid N terminus in the rat was reported [12].

In the cerebellum, expressions of $\operatorname{TR} \alpha$ and $\operatorname{TR} \beta$ that regulate the target genes were reported [13]. Recent studies using animals with deficiency of TR have demonstrated that $\mathrm{T} 3$ acts on Purkinje cells directly through TR $\alpha 1$ expressed on the Purkinje cells and not on the granule cells [14]. In functional studies, TR $\beta 1$ is also thought to be important in cerebellar development despite its low mRNA content [15]. These observations clearly identify the critical role of TR in normal development and growth of cellebellum. However, the effects of thyroid hormone or expression of TRs in medulloblastoma, a malignant tumor derived from the cerebellum, remain poorly understood. 
In this study, we used expression experiments to analyze the status of TR expression in human medulloblastoma cells, HTB-185 cells, and we studied the effects of T3 on the levels of TR expression. In addition, we attempted to clarify the mechanisms by which T3 regulates the rate of TR transcription. Our present findings showed different patterns of TR expression from the normal cerebellum and down-regulation of TR genes by T3, suggesting that TRs may play certain roles of TRs and auto-regulation by T3 in medulloblastoma cells.

\section{Materials and Methods}

\section{Materials}

Actinomycin D, cycloheximide and T3 were purchased from Sigma (St Louis, MO, USA). Dulbecco's modified Eagle's medium (DMEM) and sera were purchased from Gibco BRL (Grand Island, NY, USA).

\section{Cell culture}

Human medulloblastoma derived HTB-185 cells [16] were acquired from American Type Culture Collection (Manassas, VA, USA). They were maintained in Dulbecco's modified Eagle's medium supplemented with $10 \%(\mathrm{v} / \mathrm{v})$ fetal bovine serum (FBS), 100 units $/ \mathrm{ml}$ penicillin and $100 \mu \mathrm{g} / \mathrm{ml}$ streptomycin (Gibco BRL). Cells were grown on $150 \mathrm{~cm}^{2}$ cell culture plates for 48 h. Then cells were cultured in DMEM containing $10 \%$ $(\mathrm{v} / \mathrm{v})$ charcoal-stripped FBS in the presence or absence of $100 \mathrm{nM} \mathrm{T3}$. To remove steroid and thyroid hormones, FBS was treated for $24 \mathrm{~h}$ at $4^{\circ} \mathrm{C}$ with $50 \mathrm{mg} / \mathrm{ml}$ of activated charcoal (Sigma) and $30 \mathrm{mg} / \mathrm{ml}$ of anion exchange resin (type AGX-8, analytical grade, BioRad). After the cells were harvested, total RNA was extracted by Isogen (Nippon Gene).

\section{$R T-P C R$}

Two $\mu$ g of total RNA was reverse transcribed into first-strand cDNA for $2 \mathrm{~h}$ at $37^{\circ} \mathrm{C}$ using Moloney murine leukemia virus reverse transcriptase (Boehringer Mannheim, Indianapolis, IN). TRs cDNA were amplified from $3 \mu \mathrm{l}$ cDNA (from total $20 \mu \mathrm{l}$ ) using the following primer combinations of sense/antisense primers (TR $\alpha 1$ : 5'-atgatcggggectgccacgcc-3'/5'-ctctccaggctcct ccccaccca-3': nucleotide 1199 to 1360; TR $\alpha 2$ : 5'-atggct gtcacgggagcagctcaag-3'/5'-gcttcagggagaggctgcattgcc-3': nucleotide 895 to 1532 ; TR $\beta 1$ : 5'-atgacagaaaatggecttac agctt-3'/5'-tcttgctgtcatccagcaccaaatc-3': nucleotide 300 to 840; TR $\beta 2$ : 5'-atgaacttactgtatcaagaaata-3'/5'-cttgctgt catccagcaccaaatc-3': nucleotide 106 to 687 ). The PCR carried out consisted of $94^{\circ} \mathrm{C}$ denaturing for $1 \mathrm{~min}$, $60^{\circ} \mathrm{C}$ annealing for $2 \mathrm{~min}$ and $72^{\circ} \mathrm{C}$ extension for $2 \mathrm{~min}$, followed by a 15 -min final extension at $72^{\circ} \mathrm{C}$. The PCR was performed for 20, 25, 30, 35, 40, and 45 cycles to determine what amplification was in the linear range. Then, PCR of TR $\alpha 1$ and $\beta 1$ was carried out for 30 cycles ( $\beta$-actin for 20 cycle). Twenty $\mu \mathrm{l}(50 \mu \mathrm{l}$ total) PCR products were visualized by agarose gel electrophoresis. The visualized band densities were analyzed by NIH-Image version $1.62 \mathrm{f}$ software and corrected by $\beta$-actin that was amplified simultaneously, $\beta$-actin sense: 5 '-gctcgtcgtcgacaacgg-3', and $\beta$-actin antisense: 5 '-caaacatgatctgggtcatcttctc-3'.

\section{Northern blot analysis}

Total RNA was extracted from the HTB-185 cells using Isogen. Aliquots of $20 \mu \mathrm{g}$ of total RNA were separated by electrophoresis on a $1.2 \%$ formaldehydeagarose gel. Size-separated RNA was transferred onto a nylon membrane (GeneScreen Plus). The PCR product subcloned into the pGEMT vector (Promega) was digested with endonuclease and used to generate ${ }^{32} \mathrm{P}$ labeled cRNA probe with RNA polymerase (SP6 or T7). After overnight hybridization at $60^{\circ} \mathrm{C}$, the membrane was washed twice in $2 \times \mathrm{SSC}$ at room temperature for $15 \mathrm{~min}$ and twice in $0.1 \times \mathrm{SSC}$ and $1 \% \mathrm{SDS}$ at $70^{\circ} \mathrm{C}$ for $60 \mathrm{~min}$, then exposed to X-ray film (Kodak XAR-5) at $-70^{\circ} \mathrm{C}$ for $16 \mathrm{~h}$. The hybridization bands were quantitatively measured using Adobe Photoshop 4.0 (Adobe Systems Corp., San Jose, CA) and NIH Image (Scion Corp., Frederick, MD). The experiment was repeated three times.

\section{Results}

TR 1, TR $\alpha 2$ and $\beta 1 m R N A$ are expressed in HTB 185 cells

To define the pattern of TR isoform expression in HTB185 cells, we performed Northern blot analysis and RT-PCR using specific primers and probes for 
each TR isoform. As shown in Fig. 1-A, Northern blot analysis of HTB185 cells revealed a single species of only TR $\alpha 2 \mathrm{mRNA}, 2.6 \mathrm{~kb}$ in length, which is identical in size to that of the intact central nervous system. In addition, TR $\alpha 1$ and TR $\beta 1$ mRNAs were determined by RT-PCR method but not by Northern blot analysis. However, TR $\beta 2$ mRNA was not identified under the same condition (Fig. 1-B). These findings suggested relatively higher expression levels of TR $\alpha 2 \mathrm{mRNA}$ than those of TR $\alpha 1$ and TR $\beta 1$ isoforms and less expression of TR $\beta 2$ mRNA in HTB185 cells.

\section{T3 decreased the TR $1, T R \alpha 2$ and TR $\beta 1$ mRNA levels in a dose-dependent manner}

As shown in Fig. 1-A, treatment of $100 \mathrm{nM}$ T3 for 24 $\mathrm{h}$ caused a significant decrease of TR $\alpha 2$ mRNA levels by Northern blot analysis ( $20 \%$ of the control level). Addition of T3 did not affect protein concentrations during these periods and $\mathrm{T} 3$ concentrations. In addition, Fig. 1-B depicts the decreasing levels of TR $\alpha 1$ mRNA for RT-PCR analysis of HTB185 cells treated with $100 \mathrm{nM}$ T3. TR $\alpha 1 \mathrm{mRNA}$ levels were reduced to $21 \%$ of the control level, at $100 \mathrm{nM}$. Similarly, TR $\beta 1$
mRNA levels were also reduced to $44 \%$ of the control levels at $100 \mathrm{nM}$ in Fig. 1-B. There were no significant changes in $\beta$-actin mRNA levels under the same conditions.

Effects of inhibition of RNA synthesis on the steadystate and T3-induced reduction of TR $m R N A$ levels

To determine whether the T3-induced down-regulation of TR mRNA levels was due to decreased stability of the mRNA, HTB-185 cells were incubated with or without $100 \mathrm{nM}$ T3 for $2 \mathrm{~h}$, followed by treatment with actinomycin D $(5 \mu \mathrm{g} / \mathrm{ml})$. Northern blot analysis revealed that the TR $\alpha 2$ mRNA was increased to $119 \%$ by the addition of actinomycyin $\mathrm{D}$ in the absence of $\mathrm{T} 3$ after $4 \mathrm{~h}$ incubation and to $144 \%$ in the presence of T3. These levels then revealed a time-dependent decrease. The half-life of the TR $\alpha 2$ mRNA (determined following $4 \mathrm{~h}$ of incubation with actinomycin D) was $7.9 \mathrm{~h}$ in controls and $2.9 \mathrm{~h}$ in $\mathrm{T} 3$ treated cells (Fig. 2-A).

Moreover, to determine whether the T3-mediated down-regulation of TR $\alpha 1$ and TR $\beta 1$ mRNA level was also due to decreased stability of the mRNA, similar experiments by RT-PCR analysis were carried out.
A

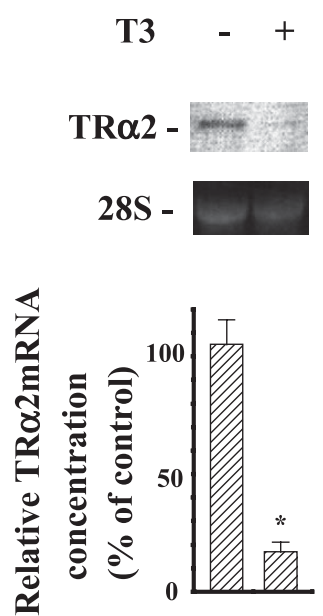

B

T3
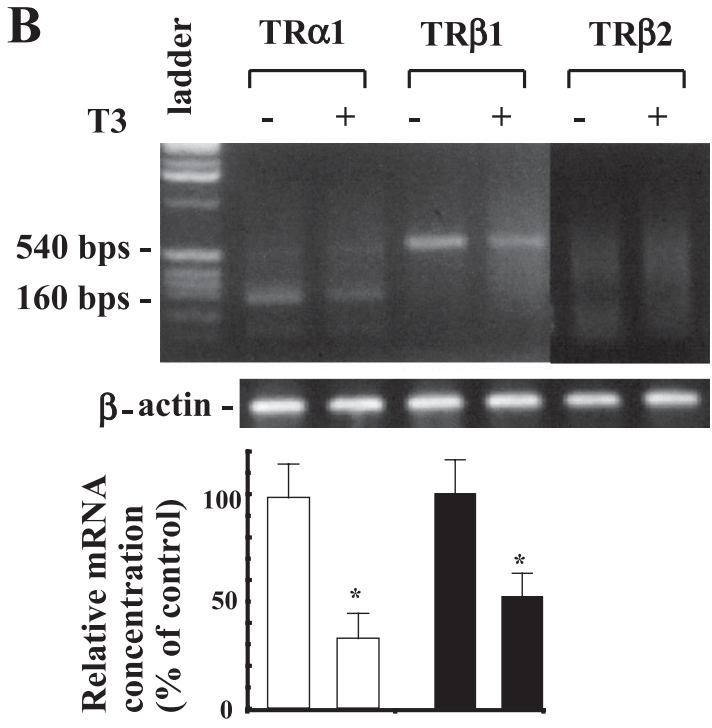

Fig. 1. Decrease in TRs mRNA expression in HTB185 cells following exposure to T3. HTB185 cells were incubated for $24 \mathrm{~h}$ in the absence and presence of $100 \mathrm{nM}$ T3. A: $20 \mu \mathrm{g}$ of total RNA were fractionated and blotted as described in Materials and Methods. Blots were probed with a 32P-labelled TR $\alpha 2$ cRNA. A representative autoradiogram is shown. Relative TR $\alpha 2$ mRNA levels are expressed as percentage of the control value from three independent experiments below the autoradiogram. B: $2 \mu \mathrm{g}$ of total RNA was reverse transcribed into first-strand cDNA for $2 \mathrm{~h}$ at $37^{\circ} \mathrm{C}$ using Moloney murine leukemia virus reverse transcriptase. TRs cDNA were amplified from $3 \mu \mathrm{l}$ cDNA (from total $20 \mu \mathrm{l}$ ) using the primer and PCR conditions described in Materials and Methods. Relative TR $\alpha 1$ and $\beta 1 \mathrm{mRNA}$ levels are expressed as percentage of the control value from three independent experiments below the RT-PCR figure. *, $\mathrm{P}<0.05$, significantly different from $-\mathrm{T} 3$ groups. 

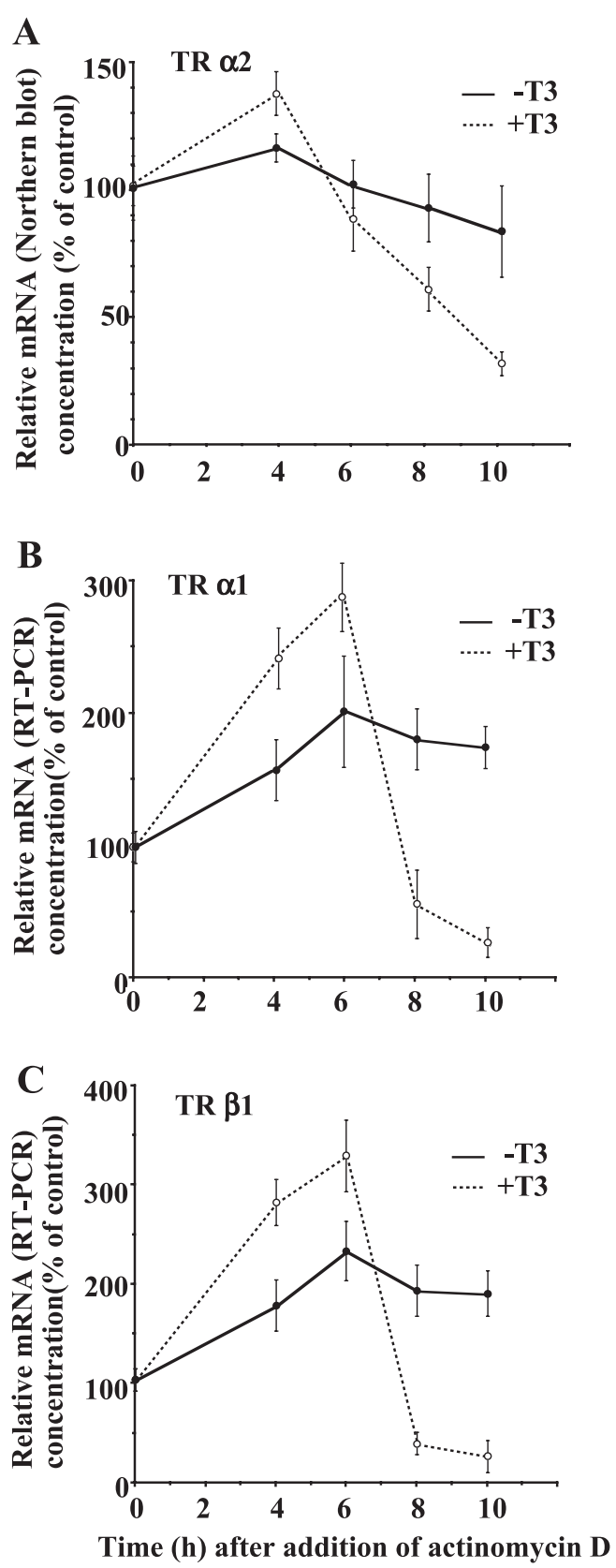

Fig. 2. Stability of TR mRNAs in control and T3-treated cells. Cells were incubated with or without $100 \mathrm{nM}$ T3 for $2 \mathrm{~h}$. They were then incubated with actinomycin D $(5 \mu \mathrm{g} / \mathrm{ml})$ for $0,4,6,8$ and $10 \mathrm{~h}$. A: Northern blot analysis for TR $\alpha 2$ using total RNA was carried out. Autoradiographic bands were quantified by laser densitometry and TR $\alpha 2$ mRNA levels were determined as the percentage of mRNA remaining (compared with cells not exposed to actinomycin D) versus time of exposure to actinomycin D. B, C: RT-PCR analysis for TR $\alpha 1$ and $\beta 1$ was carried out as described in the Materials and Methods. Each point represents the mean \pm S.E. from three independent experiments.
Actinomycin D increased the levels of TR $\alpha 1$ and TR $\beta 1$ mRNA for the first $6 \mathrm{~h}$, after which these levels revealed a time-dependent decrease. The rate of decrease of both TR $\alpha 1$ and TR $\beta 1$ mRNA in the T3-treated cells was rapid compared to those in controls, suggesting that T3 accelerates the degradation of TR $\alpha 1$ and TR $\beta 1$ mRNA.

\section{Effects of inhibition of protein synthesis on T3-induced reduction of TR $m R N A$ levels}

Next, to determine the requirement for protein synthesis in the down-regulation of the TRs mRNA levels by T3, HTB-185 cells were incubated with or without $100 \mathrm{nM} \mathrm{T3}$ in the presence or absence of cycloheximide $(10 \mu \mathrm{g} / \mathrm{ml})$. Cycloheximide slightly enhanced basal TR mRNA expression and completely blocked the T3-mediated decrease in TR $\alpha 2$ mRNA levels by Northern blot analysis and TR $\alpha 1$ and TR $\beta 1$ mRNA by RT-PCR analysis (Fig. 3).

\section{Discussion}

Although many experiments have identified the role of thyroid hormone action in the cerebellum [17], few

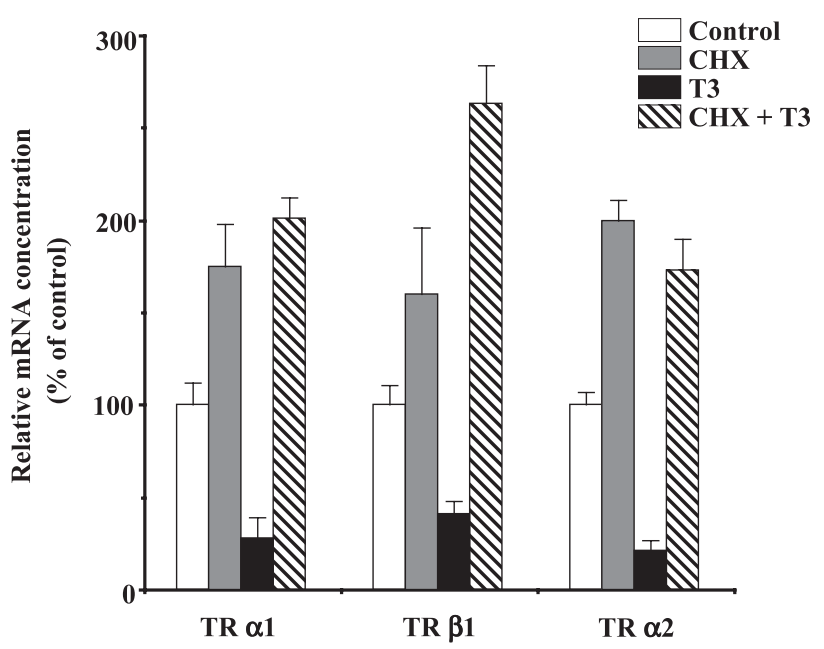

Fig. 3. Effects of cycloheximide (CHX) on the T3-induced decrease in the TRs mRNA levels. HTB185 cells were incubated for $24 \mathrm{~h}$ with or without $100 \mathrm{nM}$ T3 in the presence or absence of $10 \mu \mathrm{g} / \mathrm{ml}$ of CHX. Northern blot analysis for TR $\alpha 2$ and RT-PCR analysis for TR $\alpha 1$ or $\beta 1$ were carried out. Relative mRNA levels are expressed as percentage of control value from three independent experiments (means \pm S.E.). 
studies have focused on thyroid hormone action in medulloblastoma, a neuro-epithelial tumor of the cerebellum and the commonest central nervous system malignancy. Thyroid hormone receptor expressions, however, have been well examined in other brain tumor cells such as glioma or neuroblastoma cells [18, 19]. The data from our present study demonstrate that the levels of TR $\alpha 2$ mRNA are relatively abundant and the levels of TR $\alpha 1$ and $\beta 1$ are moderately expressed, while TR $\beta 2$ mRNA is not detectable in human medulloblastoma HTB185 cells. Although there are few reports comparing expression levels of TRs in human cellebellum under the same conditions, our findings suggest that the expression patterns of the TRs are similar to those in the intact rat cerebellum [7]. In addition, we confirmed that the expression pattern of the TRs in HTB185 cells seems to be similar to what was detected (TR $\alpha 1$, TR $\beta 1$ by RT-PCR method, TR $\alpha 2$ by Northern blot analysis) in preliminary experiments on human normal cerebellum using Premium total RNA (Clontech) (data not shown); however, the difference of the TR expression pattern between tumor and nontumor tissues in the same case has not yet to be determined.

The functions of TR $\alpha 1$ and TR $\beta 1$ in Purkinje cell differentiation have been identified $[14,15]$. In addition, previous reports using the RT-PCR method were not able to detect TR $\beta 2$ mRNA expression in the cerebellum, while low levels of TR $\beta 2$ mRNA in the Purkinje layer of the cerebellum were demonstrated by in situ hybridization histochemistry $[9,20]$, but the function of TR $\beta 2$ in the cerebellum remains unclear. $\mathrm{TR} \alpha 2$, unlike TR $\alpha 1$ or TR $\beta 1$, is not able to bind T3 and appears to exert dominant negative activity of T3-TRsdependent transactivation of TR target genes [21]. It is well known that $\mathrm{TR} \alpha 2$ is the most abundant isoform in the brain, kidney and testis $[22,23]$. In these tissues, $\mathrm{TR} \alpha 2$ is thought to modulate $\mathrm{T} 3$ responsiveness through its dominant negative activity. In the heart, $\mathrm{TR} \alpha 2$ mRNA is decreased in response to T3, while $\mathrm{TR} \alpha 2$ is increased in response to $\mathrm{T} 3$ in the liver through TR $\alpha 1$ or TR $\beta 1$ [24]. Therefore, TR $\alpha 2$ is thought to regulate the response to $\mathrm{T} 3$ in tissue specificity. Studies are in progress to determine whether the dominant expression of TR $\alpha 2$ in medulloblastoma cells provides certain functions in tumor growth.

The data presented in Fig. 1 indicate that expressions of TR $\alpha 1, \alpha 2$, and $\beta 1$ mRNA were down-regulated by adding T3. To study a possible change in TR mRNA stability, additional experiments were performed under treatment with actinomycin D. Actinomycin D acutely increased the levels of mRNA. This is consistent with our previous report [25]. The mRNA change graphs of TR $\alpha 1$ and TR $\beta 1$ in the Fig. 2-B, C show very similar peak times at $6 \mathrm{~h}$. The graph of TR $\alpha 2$ in Fig. 2-A depicts $4 \mathrm{~h}$. This timelag may be explained by the experimental differences (TR $\alpha 1$ and TR $\beta 1$ detected by RT-PCR, TR $\alpha 2$ detected by Northern blot analysis). We analyzed the half-life of each TR mRNA from Fig. 2 after the peak time. Our findings clearly showed that the half-life decreases in the three kinds of TR mRNA in the T3-treated cells were shorter than those of controls. Therefore, we conclude that the decrease in the mRNA in the T3-treated cells is due mainly to acceleration of the degradation of the TR genes. In addition, inhibition of protein synthesis with cycloheximide increased the basal levels of TRs mRNA and completely blocked the T3-induced decrease in TRs mRNA levels in Fig. 3, suggesting that the effects of T3 are dependent on ongoing protein synthesis. Moreover, the finding that treatment with either actinomycin D or cycloheximide increased basal TR mRNA expression indicates the possible existence of certain short-lived proteins that suppress the TRs gene transcription or the TR mRNA turnover. Thus, a detailed understanding what kinds of protein are involved in the T3-mediated TR mRNA degradation is of considerable future importance.

Regulation of mRNA stability is currently considered to be a major control point in gene expression [26]. In addition, it is well established that $\mathrm{T} 3$ regulates many kinds of gene expression in pre-mRNA splicing [27] as well as in translational and post-translational processes $[28,29]$. There is a possibility that mRNA stability regulators like $\mathrm{HuD}$ protein, which is reported to induce TR $\alpha 1$ mRNA stability in the absence of T3 in neuroblastoma N2a cells [30], may be involved in the TR mRNA stability in medulloblastoma. In the effect of T3 on TR mRNA, up-regulation of TR $\beta 1$ mRNA in the oligodendriglial cell and cerebral astrocyte, downregulation of TR $\beta 1$ and TR $\alpha 2$ in pituitary and TR $\alpha 1$ and $\alpha 2$ in the cerebral astrocyte have been identified [31-33], suggesting that the tissue- and isoform specificity may be related to the TR mRNA expression regulated by T3. Recently, it was reported that the multiple TR $\beta 1$ mRNA variants with alternately spliced 5'-UTR determined the cell-specific expression [34]. Moreover, the most recent report shows that $\mathrm{T} 3$ decreases 
the TR $\alpha 1$ mRNA by proteosome-dependent degradation in cardiomyocytes [35]. Taken together, TR mRNA stability by $\mathrm{T} 3$ may be regulated in a tissue-specific manner by a complex array of posttranscriptional mechanisms.

In summary, the present study demonstrated that 1) the expression of TR $\alpha 2$ mRNA was relatively higher than those of TR $\alpha 1$ or TR $\beta 1$ in HTB185 cells, and 2) T3 accelerated the degradation time of these kinds of TR isoform mRNA. This is the first study to show the regulation of $\mathrm{T} 3$ in its receptors in human medulloblastoma cells.

\section{References}

1. Oppenheimer JH, Schwartz HL (1997) Molecular basis of thyroid hormone-dependent brain development. Endocr Rev 18: 462-475.

2. Thompson CC, Weinberger C, Lebo R, Evans RM (1987) Identification of a novel thyroid hormone receptor expressed in the mammalian central nervous system. Science 237: 1610-1614.

3. Bradley DJ, Young WS 3rd, Weinberger C (1989) Differential expression of $\alpha$ and $\beta$ thyroid hormone receptor genes in rat brain and pituitary. Proc Natl Acad Sci USA 86: 7250-7254.

4. Onate SA, Tsai SY, Tsai MJ, O'Malley WO (1995) Sequence and characterization of a coactivator for the steroid hormone receptor superfamily. Science 270: 1354-1357.

5. Monden T, Wondisford FE, Hollenberg AN (1997) Isolation and characterization of a novel ligand-dependent thyroid hormone receptor-coactivating protein. J Biol Chem 272: 29834-29841.

6. Kariya Y, Moriya T, Suzuki T, Chiba M, Ishida K, Takeyama J, Endoh M, Watanabe M, Sasano H (2005) Sex steroid hormone receptors in human skin appendage and its neoplasms. Endocr J 52: 317-325.

7. Cook CB, Koenig RJ (1990) Expression of erbA $\alpha$ and $\beta$ mRNAs in regions of adult rat brain. Mol Cell Endocrinol 70: 13-20.

8. Hodin RA, Lazar MA, Chin WW (1990) Differential and tissue-specific regulation of the multiple rat c-erbA messenger RNA species by thyroid hormone. $J$ Clin Invest 85: 101-105.

9. Lechan RM, Qi Y, Berrodin TJ, Davis KD, Schwartz HL, Strait KA, Oppenheimer JH, Lazar MA (1993) Immunocytochemical delineation of the thyroid hormone receptor $\beta 2$-like immunoreactivity in the rat central nervous system. Endocrinology 132: 2461-2469.

10. Sherer TT, Sylvester SR, Bull RJ (1993) Differential expression of c-erbA mRNAs in the developing cerebellum and cerebral cortex of the rat. Biol Neonate 63: 26-34.

11. Forrest D, Hallböök F, Persson H, Vennström B (1991) Distinct functions for thyroid hormone receptors $\alpha$ and $\beta$ in brain development indicated by differential expression of receptor genes. EMBO J 10: 269-275.

12. Williams GR (2000) Cloning and characterization of two novel thyroid hormone receptor $\beta$ isoforms. Mol Cell Biol 20: 8329-8342.

13. Strait KA, Schwartz HL, Seyhold VS, Ling NC, Oppenheimer JH (1991) Immunofluorescence localization of thyroid hormone receptor protein $\beta 1$ and variant $\alpha 2$ in selected tissues: cerebellar Purkinje cells as a model for $\beta 1$ receptor-mediated developmental effects of thyroid hormone in brain. Proc Natl Acad Sci USA 88: 3887-3891.

14. Heuer H, Mason CA (2003) Thyroid hormone induces cerebellar Purkinnje cell dendritic development via the thyroid hormone receptor $\alpha 1$. Neuroscience 23: 10604 10612.

15. Strait KA, Zou L, Oppenheimer JH (1992) $\beta 1$ isoformspecific regulation of a triiodothyronine-induced gene during cerebellar development. Mol Endocrinol 6: 1874-1880.

16. Hashida T, Yamada M, Hashimoto K, Shibusawa N, Monden T, Satoh T, Mori M (2002) A novel TRHPFTAIRE protein kinase 1 pathway in the cerebellum: subtractive hybridization analysis of TRH-deficient mice. Endocrinology 143: 2802-2811.

17. Koibuchi N, Jingu H, Iwasaki T, Chin WW (2003) Current perspectives on the role of thyroid hormone in growth and development of cerebellum. Cerebellum 2: 279-289.

18. Pastor R, Bernal J, Rodriguez-Peña A (1994) Unliganded c-erbA/thyroid hormone receptor induced trkB expression in neuroblastoma cells. Oncogene 9: 1081-1089.

19. Lebel JM, Dussault JH, Puymirat J (1994) Overexpression of the $\beta 1$ thyroid hormone receptor induces differentiation in neuro-2a cells. Proc Natl Acad Sci USA 91: 2644-2648.

20. Li M, Boyages SC (1996) Detection of extended distribution of $\beta 2$-thyroid hormone receptor messenger ribonucleic acid (RNA) in adult rat brain using complementary RNA in situ hybridization histochemistry. Endocrinology 137: 1272-1275.

21. Katz D, Lazar MA (1993) Dominant negative activity of an endogenous thyroid hormone receptor variant (a2) is due to competition for binding sites on target genes. J Biol Chem 268: 20904-20910.

22. Strait KA, Schwartz HL, Perez-Castillo A, Oppen- 
heimer JH (1990) Relationship of c-erbA mRNA content to tissue triiodothyronine nuclear binding capacity and function in developing and adult rats. $\mathrm{J}$ Biol Chem 265: 10514-10521.

23. Hodin RA, Meng S, Chamberlain SM (1994) Thyroid hormone responsiveness is developmentally regulated in the rat small intestine: a possible role for the $\alpha-2$ receptor variant. Endocrinology 135: 564-568.

24. Sadow PM, Chassande O, Koo EK, Gauthier K, Samarut J, Xu J, O’Malley BW, Weiss RE (2003) Regulation of expression of thyroid hormone receptor isoforms and coactivator in liver and heart by thyroid hormone. Mol Cell Endocrinol 203: 65-75.

25. Monden T, Yamada Y, Konaka S, Satoh T, Ezawa T, Iwasaki T, Mori M (1995) Transcriptional down-regulation by epidermal growth factor of TRH receptor mRNA in rat pituitary cells. $J$ Mol Endocrinol 15: 7379.

26. Guhaniyogi J, Brewer G (2001) Regulation of mRNA stability in mammalian cells. Gene 265: 11-23.

27. Aniello FA, Couchie D, Brioux A-M, Gripois D, Nunez J (1991) Proc Natl Acad Sci USA 88: 4035-4039.

28. Liu D, Waxman DJ (2002) Post-transcriptional regulation of hepatic NADPH-cytochrome P450 reductase by thyroid hormone: independent effects on poly(A) tail length and mRNA stability. Mol Pharmacol 61: 10891096.

29. Baas D, Puymirat J, Sarlieve LL (1998) Posttranscriptional regulation of oligodendroglial thyroid hormone
(T3) receptor $\beta 1$ by T3. Int J Dev Neurosci 16: 461467.

30. Cuadrado A, Navarro-Yubero C, Furneaux H, Munoz A (2003) Neuronal HuD gene encoding a mRNA stability regulator is transcriptionally repressed by thyroid hormone. J Neurochem 86: 763-773.

31. Hastings ML, Ingle HA, Lazar MA, Munroe SH (2000) Post-transcriptional regulation of thyroid hormone receptor expression by cis-acting sequenced and a naturally occurring antisense RNA. J Biol Chem 275: 11507-11513.

32. Lazar MA, Chin WW (1988) Regulation of two c-erbA messenger ribonucleic acids in rat $\mathrm{GH} 3$ cells by thyroid hormone. Mol Endocrinol 2: 479-484.

33. Lebel JM, L'herault S, Dussault JH, Puymirat J (1993) Thyroid hormone up-regulates thyroid hormone receptor $\mathrm{b}$ gene expression in rat cerebral hemisphere astrocyte cultures. Glia 9: 105-112.

34. Frankton S, Harvey CB, Gleason LM, Fadel A, Williams GR (2004) Multiple messenger ribonucleic acid variants regulate cell-specific expression of human thyroid hormone receptor $\beta 1$. Mol Endocrinol 18: 1631-1642.

35. Kenessey A, Ojamaa K (2005) Ligand-mediated decrease of thyroid hormone receptor- $\alpha 1$ in cardiomyocytes by proteosome-dependent degradation and altered mRNA stability. Am J Physiol Heart Circ Physiol 288: H813-H821. 